\title{
Education in the library: luxury or a citizen's guaranteed quality of life
}

\author{
Ekaterina Asonova ${ }^{1 *}$, Liubov Borusyak $^{1}$, Elena Romanicheva $^{1}$, and Ksenia Kikteva ${ }^{1}$ \\ ${ }^{1}$ Moscow City University, Institute of System Projects, Laboratory of Sociocultural Educational \\ Practices, Moscow, Russia
}

\begin{abstract}
The article studies the role of city libraries in school education based on expert interviews carried out with Moscow teachers, librarians, teenagers, and their parents. The study is relevant due to the importance of city libraries in the educational process and their insufficient use in practice. This is the first comprehensive study of standardized interaction between schools and city libraries. The research has demonstrated that ties between these institutions and the process of their interaction have a personal and informal nature. Today, public libraries are information and education resources for school only to a small extent. Most teachers do not see any point in collaborating with libraries since their communication with librarians is not properly regulated. As a rule, successful examples of such interaction are not associated with established rules but rather with a personal interest conditioned by subjective, often random reasons. An essential characteristic of this communication is event-based learning, the use of verbal practices and educational games, as well as a stable educational orientation. Children as participants in the educational process have minimum engagement in this field. It is a rare case that libraries are regarded as a place for independent learning where students work with the necessary sources to conduct scientific research and engage in project activity. In most cases, city libraries attract teachers with their studentoriented events or activities. At the same time, libraries are rarely used in the educational process. Their role does not always involve working with collections or developing children's need for independent reading. The latter can be satisfied by visiting a local library and addressing reading lists.
\end{abstract}

Keywords: city library, reading infrastructure, event-based learning, school, communication, working with library collections.

\section{Introduction}

The Moscow City University prepares future teachers for working in open education of the Russian capital. To improve the existing educational curricula and develop new teaching methods, the institution is studying the gaps that can be filled with the use of urban educational infrastructures. The Laboratory of Sociocultural Educational Practices at Moscow City University examined reading infrastructure [1]. Then libraries were considered as popular educational locations for modern schoolchildren. However, we

${ }^{*}$ Corresponding author: asonovaea@mgpu.ru 
interviewed participants in educational relations and revealed that libraries can become such objects only if they are included in the educational process [2]. While studying city libraries (there are a lot of scientific works on the involvement of school libraries in the educational process [3-7], we put forward the following hypothesis: expanding the boundaries of school education through the resources of city libraries helps to improve the quality of education received by children and the quality of people's life [8-10], including both teachers and students of Moscow schools.

\section{Methods}

The study results are based on the analysis of 18 expert interviews carried out with language and literature teachers and librarians from public and private schools of Moscow in 2019-2020 academic year. We also considered the materials provided by eight focus groups, including Moscow teachers, librarians, teenagers, and their parents, in the same period.

\section{Results}

While analyzing the collected data, we revealed specific features of this interaction.

The first feature relates to event-based learning and personal ties, which refers to the quality of communication between educational institutions and city libraries. First of all, we need to emphasize the predominant personal and informal nature of such ties. Although city authorities actively support their development (in recent years, they have organized several large projects aimed at improving educational interaction between libraries and schools, for example, the "First-class reader" contest for first-grade students, the "School day in the library" interdepartmental educational project), meaningful ties are built with a sufficiently high degree of independence of their participants. Teachers are the most common initiators since they can take on the role of the ordering customer/producer and manage this process.

The study has demonstrated that public libraries rarely serve as information and education resources for school studies of literature and other humanities. Teachers address public libraries only if they face a shortage of school library resources: this refers to library collections, various extracurricular activities, and willingness to take into account the teacher's requests and fulfil them. Most teachers do not see any point in collaborating with public libraries since their communication with librarians is not properly regulated. As a rule, successful examples of such interaction are not associated with established rules but rather with a personal interest of both teachers and librarians conditioned by subjective, often random reasons.

Five teachers out of 18 respondents (primary school teachers and those working with the fifth and sixth grades) shared their experience of interacting with children's libraries. Three teachers initiated joint activities with librarians. Two teachers collaborated with aspiring librarians to form and hold extracurricular activities. Teachers mainly focused on the librarians' readiness to work together and their human qualities facilitating interaction. The services offered were essential but only in a favorable communication situation.

A large number of libraries involved in such interactions are within walking distance of schools. Only one library was located far away from its partner school. A teacher took her students to the far end of Moscow when she learned about the events held by this library on the Internet. She did not search for similar activities in the nearest libraries, most likely, due to the lack of accessible information.

The second essential feature of this educational communication is event-based learning, the use of verbal practices (lectures, workshops, talks) and educational games (quests and 
quizzes), as well as its stable educational nature. Children as participants in the educational process have minimum engagement in this field. Meetings with them aim at transferring ready-made knowledge, i.e. at a format of relationships close to school interactions when children are offered a set of "digested" knowledge. It is a rare case that libraries are regarded as a place for independent learning where students work with the necessary sources to conduct scientific research and engage in project activity. At the same time, libraries are a perfect location for this type of activity because it is a favorable and comfortable environment for reading and working with sources. A rich collection of printed and electronic resources, free access to them, qualified assistance from librarians in finding sources and working with them, including in the Hygge style [11], as well as the reader's ability to select resources - all this creates the necessary conditions for independent work on a creative task, study, or project.

Judging by the respondents' answers, city libraries mostly attract teachers with their student-oriented events or workshops. In some cases, students act as spectators or participants. Schoolchildren are brought to libraries for performances, festivals, movie screenings, meetings with writers and book publishers, etc., as well as to participate in various quests, games, and quizzes. In the first case, the role of schoolchildren is mostly passive and requires no special preparation. In the second case, they are more active and take part in competitions with prior preparation at school and the support of their teacher. The respondents noted the following problem: these events are connected with classical children's literature and practically ignore modern literature.

However, teachers complain that children cannot take the books they liked, including those they saw or heard of. To help a child join the library, the presence of a parent is required. If a teacher brings children to some public library, they cannot join or take any books home, as a result, children are not in constant contact with a city library.

The fact that a crucial participant (parents) falls out of an event-based "school-library" interaction is decisive for the effectiveness of this "field trip". This can be explained by two reasons: firstly, family and school do not know how libraries work with the community (sight-seeing tours, clubs, etc.); secondly, libraries are not ready for informal communication. We examined enough children's reading clubs and none of them was located in a public library.

Perhaps, it happens because many city libraries, primarily children's libraries, do not study (and, as a result, do not meet) the needs of school, family, and students. However, readers visit libraries to satisfy their needs [12]. Thus, it is necessary to arrange the functioning of libraries basing on the principle of customization, which is emphasized by foreign scholars [13-15].

All teachers who had contact with libraries told us about their events and only two respondents were aware of their regular training sessions. The topics of these classes vary greatly: some libraries introduce children to periodicals, while others present them travel books and geographical discoveries. Each lesson can cover one topic; sometimes it is a cycle that continues throughout the school year. Many teachers mentioned that it was theoretically possible to conduct lessons in a library but only one of them used this opportunity.

We determined one more component of library communication (i.e. books) but it turned out that the events held by libraries do not always involve working with collections or developing children's need for independent reading. The latter can be satisfied by visiting a local library and addressing reading lists. Currently, both school libraries and city libraries are often visited by students in search of books "from the syllabus" and books for home reading lessons. A modern student has more reasons to go to a local library where they can withdraw from the world and read, complete a class assignment, rummage through books, and write their own stories. For example, the reading log can become an interesting reading 
practice rather than a form of teachers' control over the reading progress. If students are encouraged to keep their reading log informally and creatively, they can benefit from it in the following aspects: to record what is read and mark the time left for free reading (the time factor is of great importance today); to understand their preferences; to choose a convenient format for making notes and coming up with new forms of presenting a particular book for like-minded people, etc. We should also keep in mind that readers are subjects of readers' communication. The very phenomenon of reading cannot exist without them. Furthermore, readers can discuss what has been read on the pages of their reading $\log$.

\section{Conclusion}

Since only a small number of the respondents had joint activities with children's libraries, it is impossible to get a comprehensive view of all the forms and methods of such interaction. Such communication is carried out by teachers or parents (we still have to study the specifics of their interaction with libraries), who are not quite satisfied with extracurricular activities held by school libraries. They do not limit children to literature lessons and the work with books in the classroom and understand the role of independent reading and study of sources for further learning and high quality of life.

Personal contacts between teachers and librarians are more important than standard forms of organizing such interaction.

The most common forms of interaction are extracurricular activities, contests, quests, and other types of play activity organized by library workers.

\section{References}

1. E.A. Asonova, E.S. Romanicheva, O.V. Senenko, K.S. Kikteva, Voprosy obrazovaniya, 2, 26-45 (2018)

2. E.A. Asonova, L.F. Borusyak, E.S. Romanicheva, Voprosy obrazovaniya, 1, 159-181 (2020)

3. D. Loertscher, C. Koechlin, E. Rosenfeld, The Virtual Learning Commons (Learning Commons Press, Salt Lake City, 2012)

4. D. Loertscher, C. Koechlin, S. Zwaan, E. Rosenfeld, The New Learning Commons: Where Learners Win!: Reinventing School Libraries and Computer Labs (Hi Willow Research \& Pub, Salt Lake City, 2011)

5. D. Loertscher, Teacher Librarian, 44(5), 44-47 (2017)

6. L.S.J. Farmer, Introduction to Reference and Information Services in Today's School Library (Rowman \& Littlefield Publishers, Lanham, 2014)

7. S. Cohen, I. Poitras, K. Mickens, A. Shirali, Roles of the school librarian. Empowering student learning and success. Informational brief (Northeast Comprehensive Center, Connecticut, 2018). Accessed on: December 22, 2020. [Online]. Available: http://www.nysl.nysed.gov/libdev/slssap/ncc-roles-execsumm.pdf?fbclid=IwAR0LD7q5584Zoxpt6JqQyaI2V80ejjGkq5NXrplh8o1gqxpU42V MU8AxDrc

8. M. Lincoln, E-Learning and Holocaust Education in a School Library, in E-Learning in Libraries: Best Practices (Scarecrow Press, Lanham, 2013)

9. R. Ludt, Think Big! A Resource Manual for Teen Library Programs That Attract Large Audiences (Rowman \& Littlefield Publishers, Lanham, 2020) 
10. M.N. Mallon, Partners in Teaching and Learning. Coordinating a Successful Academic Library Instruction Program (Rowman \& Littlefield Publishers, Lanham, 2020)

11. N.V. Lopatina, Bibliografiya i knigovedenie, 1(426), 84-93 (2020)

12. I.B. Mikhnova, A.A. Purnik, Effektivnaya biblioteka: kak obustroit biblioteku i sdelat ee nuzhnoi lyudyam [Efficient library: how to equip libraries and make them highly demanded] (Rossiyskaya gosudarstvennaia biblioteka dlya molodezhi, Moscow, 2018)

13. C. Harmon, M. Messina (Eds.), Customer Service in Libraries: Best Practices (Scarecrow Press, Lanham, 2013)

14. K. Smallwood, K. Becnel (eds.), Library Services for Multicultural Patrons: Strategies to Encourage Library Use (Scarecrow Press, Lanham, 2013)

15. R.M. Marrall, Developing a Library Accessibility Plan: A Practical Guide for Librarians (Rowman \& Littlefield Publishers, Lanham, 2020) 